\title{
Screening for in vitro antioxidant activities, polyphenolic contents and neuroprotective potentials of Clinopodium serpyllifolium subsp. serpyllifolium endemic to Turkey
}

\author{
Sevgi Gezici**, Didem Koçum*, Fatih Yayla**, Nazim Sekeroglu*** and Adnan A. Khan**** \\ Department of Molecular Biology and Genetics, Faculty of Science and Literature, Kilis 7 Aralik University, 79000, Kilis, Turkey \\ *Advanced Technology Application and Research Center, Kilis 7 Aralik University, Kilis, Turkey \\ **Department of Biology, Faculty of Science and Literature, Gaziantep University, 27310, Gaziantep, Turkey \\ ***Department of Horticulture, Faculty of Agriculture, Kilis 7 Aralik University, 79000, Kilis, Turkey \\ ****Division of Nephrology and Hypertension, Department of Medicine, University of California, San Diego, Suite Plaza 1, 4510 Execute Drive, San \\ Diego-92121, USA
}

\section{Article Info}

Article history

Received 16 April 2020

Revised 4 June 2020

Accepted 7 June 2020

Published online 30 June 2020

Keywords

C. serpyllifolium subsp.

serpyllifolium

neuroprotective

polyphenolic content

antioxidant

medicinal plant

\begin{abstract}
Clinopodium serpyllifolium subsp. serpyllifolium (CSS), an endemic-medicinal plant, is commonly used for treatment of irritated skin, mastitis- and prostatitis-related swelling, and inflammation, due to contain a number of triterpenes and triterpenoid saponins as well as some other bioactive substances. From this point-ofview, the aim of this study was to evaluate total polyphenolic contents, antioxidant activities and enzyme inhibitory effects of EtOH and $\mathrm{dH}_{2} \mathrm{O}$ extracts of stem and flower parts. In vitro DPPH, ABTS, FRAP, and CUPRAC assays were used for evaluation of antioxidant activities of the extracts. Neuroprotective potentials of the extracts were assessed using spectrophotometric microtiter assays towards AChE, BChE and TYR enzymes. In parallel to the experiments, total polyphenolic contents of the extracts were also determined as spectrophotometrically. According to the results of phenolic and flavonoid quantities in total, flower extracts possessed higher polyphenolic contents, comparing to those of stem extracts. EtOH extract prepared from the flower parts had the highest amount of total phenol and flavonoid $(368.11 \pm 2.02 \mathrm{mg} / \mathrm{g}$ extract as GAE and $214.03 \pm 0.98 \mathrm{mg} / \mathrm{g}$ extract as QE), while stem- $\mathrm{dH}_{2} \mathrm{O}$ extract possessed the lowest ones. In antioxidant assays, scavenging activity of the extracts on DPPH were found to be in the range of $70.86 \pm 1.07-92.14 \pm 2.03 \%$ inhibition, whilst it was determined lower for ABTS radicals. In DPPH and FRAP assays, the stem- $\mathrm{dH}_{2} \mathrm{O}$ extract exerted the weakest antioxidant activity, whereas, flower-EtOH extract showed the lowest antioxidant capacity on ABTS and CUPRAC. Enzyme inhibition on the tested enzymes were resulted in the superiority of the flowerEtOH extract, as consistent with findings of total polyphenolic contents. These findings suggest that CSS could be an anticholinesterase agent and antioxidant resource for food, pharmacology and cosmetics industries.
\end{abstract}

\section{Introduction}

Medicinal and aromatic plants (MAPs) and plant-derived products have been used since ancient times as food supplements as well as medicinal purposes in the prevention or management of certain degenerative and chronic diseases. In both developing and developed countries, there has been a huge interest in usage these plants for traditional herbal remedies to cure ailments and diseases owing to their easy availability and lower cost, alongside fewer side and toxic effects (Alam, 2019; Gezici and Sekeroglu, 2019a; Batiha et al., 2020). A number of studies have demonstrated that MAPs and phytoconstituents possess promising biological activities including antioxidant, antimicrobial, antiviral, antiseptic, antidiabetic, anti-inflammatory and anti-carcinogenic activities, which are closely related to prevent various health problems. Over the last decade, this knowledge has stimulated the increase in

Corresponding author: Dr. Sevgi Gezici

Associate Professor, Department of Molecular Biology and Genetics, Faculty of Science and Literature, Kilis 7 Aralik University, 79000, Kilis, Turkey E-mail: drsevgigezici@gmail.com; sevgigezici@kilis.edu.tr

Tel.: +90-5376348061

Copyright $@ 2020$ Ukaaz Publications. All rights reserved.

Email: ukaaz@yahoo.com; Website: www.ukaazpublications.com research of novel natural products obtained from MAPs that can provide a model to initiate the development of alternative drugs used for improving the human health in natural ways (Xu et al., 2017; Van Wyk and Wink, 2018; Wang et al., 2018).

Having excellent flora, Turkey is one of the world's richest countries in terms of plant biodiversity. Turkey's flora is estimated to contain approximately 11,700 plants taxa and over 4000 aromatic plants. Furthermore, almost ratio of $32 \%$ is recorded the endemism ratio and each year new such species are identified. Even though, there is a limited knowledge about the scientific information of MAPs, further researches are required to reveal the biological activities and pharmacological properties of Turkish plant species (Guner et al., 2012; FAO, 2018).

The genus Clinopodium belongs to the Lamiaceae family and comprises of almost 148 species around the world including Palestine, Israel, Lebanon, Syria, Jordan and Turkey. Approximately 39 species of this genus are found in Turkey and they are widely distributed in Black Sea, Southern and Mediterranean Turkey regions (Guner et al., 2012; The Plant List, 2020; TUBIVES, 2020). These species are commonly used for gastric disorders, respiratory diseases, lymphatic nodule inflammation, diabetes, hypertension, cough, headache, abdominal pain, 
wound and skin diseases by boiling hot water as infusion or tea in traditional Turkish medicine and previous phytochemical studies on this species have demonstrated the presence of oxygenated monoterpenes, menthone, pulegon, menthane type compounds, piperitenone, piperitenone oxide and saponins (Baytop, 1999; Sheab and Abu-Gharbieh, 2012; Tošić et al., 2015; Dunkić et al., 2017).

C. serpyllifolium subsp. serpyllifolium (M.Bieb.) Kuntze, known as 'Taş Nanesi' among the people, is grown naturally in the flora of Turkey. It has been traditionally used for gastrointestinal disorders, respiratory diseases, diabetes, hypertension, headache, wounds, and skin diseases, due to the presence of rich phytochemical contents in its flowers and leaves (Tošić et al., 2015; Dunkić et al., 2017; Ali-Shtayeh et al., 2018).

Several studies have focused on anti-inflammatory, analgesic, gastroprotective, antiseptic, antirheumatic, central nervous system stimulant, antimicrobial, anti-biofilm formation and allelochemical activities of $C$. serpyllifolium subsp. serpyllifolium. (Gulluce et al., 2004; Abu-Gharbieh et al., 2013; Shehab and Abu-Gharbieh, 2012; Abu-Gharbieh and Ahmed, 2016; Ali-Shtayeh et al., 2018). Nonetheless, to the best of our knowledge, neuroprotective activities of C. serpyllifolium subsp. serpyllifolium (CSS) combined with the other assays have not been reported elsewhere previously, in the way this research could be assumed as the first report for the literature. Thus, this study was performed to determine the effect of different extraction solvents on the total polyphenolic contents, and to evaluate the antioxidant, and enzyme inhibitory potentials of CSS.

\section{Materials and Methods}

\subsection{Plant material}

The plant material was collected in the blooming season from Gaziantep province, located in South-Eastern part of Turkey. The plant sample was taxonomically identified by a senior taxonomist Research Assistant Fatih YAYLA whose voucher specimens with GAUN5056 herbarium number are preserved at the Herbarium of Biology Department, Gaziantep University, Gaziantep-Turkey (Figure 1).

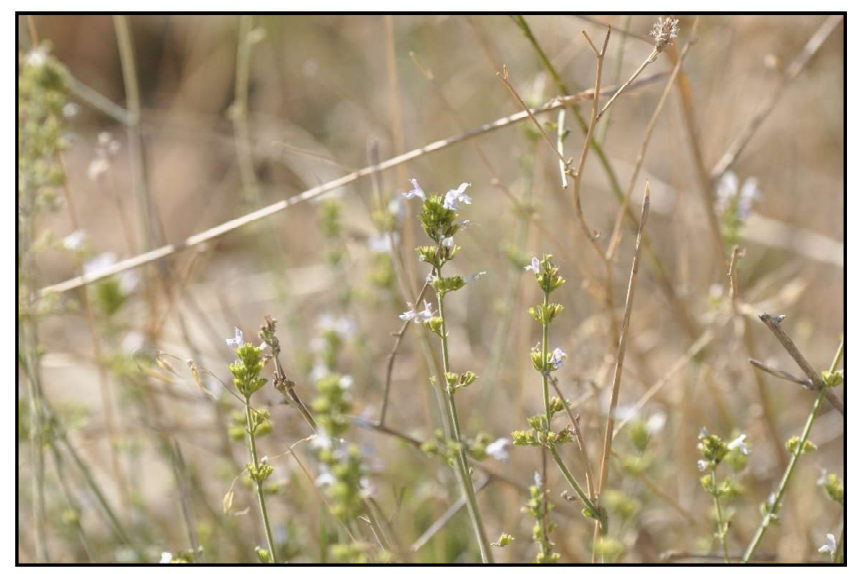

Figure 1: The stems and flowers of C. serpyllifolium subsp. serpyllifolium (M.Bieb.) Kuntze.

\subsection{Preparation of crude extracts}

To prepare the extracts, dried in shade and powdered plant samples (40 g) obtained from the stem and flower parts were individually extracted with $250 \mathrm{ml}$ ethanol (EtOH-70\%) and distilled water
$\left(\mathrm{dH}_{2} \mathrm{O}\right)$ using maceration method at the room temperature almost $48 \mathrm{hs}$. Then, the samples were filtered and ethanol was evaporated using a rotary evaporator (Sigma Aldrich, USA). The extracts were freeze-dried, and kept at $+4^{\circ} \mathrm{C}$ until analyzed. The extracts yields of the plant $(\mathrm{w} / \mathrm{w} \%)$ are given in the Table 1 .

\subsection{Total polyphenolic content analyses}

Phytochemical analyses of the extracts were performed as spectrophotometrically according to the method of previous researches (Singleton and Rossi, 1965; Woisky and Salatino, 1998; Gezici and Sekeroglu, 2019b) with slightly modifications. Phenolic compounds in total (TPC) were determined in accordance with slightly modified Folin-Ciocalteau's method, when total flavonoid content (TFC) of the extracts was calculated by Aluminum Chloride Colorimetric method. Absorbance of the reaction mixtures was measured with a Thermo Lab systems 408 Multiskan multiplate spectrophotometer. The total phenolic and flavonoid contents of the extracts were expressed as Gallic Acid Equivalent (GAE) and Quercetin Equivalent (QE) (mg/g extract), respectively.

\subsection{Free radical scavenging antioxidant assays}

Free radical scavenging activities of the EtOH and $\mathrm{dH}_{2} \mathrm{O}$ extracts obtained from stem and flowers of CS were analyzed by using 2,2diphenyl-1-picrylhydrazyl (DPPH) and 2,2'-azino-bis(3ethylbenzothiazoline-6-sulphonic acid) ABTS with some modified spectrophotometric method of Blois (1958) and Re et al. (1999). For analyses, the extracts and references antioxidant were dissolved in DMSO and diluted from 1000 to $100 \mu \mathrm{g} / \mathrm{mL}$ at varied concentrations. The analyses were run in triplicates and the results were expressed as inhibition percentage with standard deviation (SD). The DPPH and ABTS antioxidant results of the extracts were respectively compared with Ascorbic acid and Trolox employed as the references.

\subsection{Ion reducing antioxidant assays}

Ferric reducing antioxidant power (FRAP) and Cupric ion reducing capacity (CUPRAC) of the extracts were evaluated as spectrophotometrically according to the method of Oyaizu (1986) and Nguyen et al. (2015) with slight modifications. The tested samples and commercial antioxidant standard were dissolved in DMSO and diluted from 1000 to $100 \mu \mathrm{g} / \mathrm{mL}$ at varied concentrations. Analyses were achieved in triplicates, and increased absorbance of the reaction meant increased reducing power capacity. The ion reducing capacities of the extracts were compared to that of Trolox employed as a reference antioxidant.

\subsection{Neuroprotective activities}

Neuroprotective effects of the EtOH and $\mathrm{dH}_{2} \mathrm{O}$ extracts of stem and flowers of CSS were assessed through enzyme inhibition assays on AChE (acetylcholinesterase), BChE (butyrylcholinesterase), and TYR (tyrosinase). Enzyme inhibition activities of the extracts on cholinesterases and TYR were measured by slightly modified spectrophotometric method of Ellman et al. (1961) and Sekeroglu et al. (2012). Electric eel AChE (Type-VI-S, EC 3.1.1.7, Sigma, St. Louis, MO, USA) and horse serum BChE (EC 3.1.1.8, Sigma, St. Louis, MO, USA) were used, whereas acetylthiocholine iodide and butyrylthiocholine chloride (Sigma, St. Louis, MO, USA) were employed as substrates of the reaction, respectively. 5,5-Dithio- 
bis(2-nitrobenzoic)acid (DTNB, Sigma, St. Louis, MO, USA) was used for the measurement of the anticholinesterase activity. The modified dopachrome method with L-DOPA as substrate was used to evaluate the inhibition of tyrosinase (EC 1.14.1.8.1, $30 \mathrm{U}$, mushroom tyrosinase, Sigma). All the reagents and conditions were same as described in our previous publications (Senol et al., 2018; Gezici and Sekeroglu, 2019b). Percentage of inhibition of the tested enzymes was determined by comparison rates of reaction the samples relative to blank (ethanol in phosphate buffer $\mathrm{pH}=8$ ). Galanthamine (Sigma, St. Louis, MO, USA) was employed as reference anticholinesterase, and $\alpha$-Kojic acid (Sigma, St. Louis, MO, USA) was used as the reference for tyrosinase inhibition assay.

\subsection{Statistical analysis}

All the assays were performed at least triplicate. The data taken from three independent experiments was expressed as mean and standard deviation of mean (mean $\pm \mathrm{SD}$ ). The measurements and calculations were evaluated by one-way analysis of variance (ANOVA), followed by Tukey's significant difference post hoc test, and SPSS v22.0 software was used for all experimental analysis. $P$ value of $<0.05^{*}$ was considered to be statistically significant and $p<0.01 * *$ considered to be very significant.

\section{Results}

\subsection{Total polyphenolic contents}

Extraction yields of the EtOH and $\mathrm{dH}_{2} \mathrm{O}$ extracts of the stem and flower parts of CSS were determined as $2.32 \%, 2.79 \%, 8.59 \%$, and $0.42 \%(\mathrm{w} / \mathrm{w})$, respectively. The maximum extraction yield was obtained with stem- $\mathrm{dH}_{2} \mathrm{O}$ extracts $(8.59 \%)$, while, the lowest extract yield was measured with water extract from the flower part (0.42\%) (Table 1).

Total phenolic and flavonoid contents of the extracts obtained from stem and flower parts were tested spectrophotometrically and calculated the contents according to the equations. Equations for total phenolic quantities of the extracts were determined in accordance with the equation ( $\left.\mathrm{y}=0.9144 \mathrm{x}-0.643, \mathrm{r}^{2}=0.9905\right)$ as $\mathrm{GAE}(\mathrm{mg} / \mathrm{g}$ extract), whereas the equation $\left(\mathrm{y}=0.9344 \mathrm{x}-0.703, \mathrm{r}^{2}=0.9967\right)$ as $\mathrm{QE}(\mathrm{mg} / \mathrm{g}$ extract) were used to determine their flavonoid contents in total.

Table 1: Extraction yields (w/w\%) and total polyphenolic contents of CSS extracts at $1000 \mu \mathrm{g} / \mathrm{ml}$

\begin{tabular}{|c|c|c|c|c|}
\hline $\begin{array}{l}\text { Plant } \\
\text { parts }\end{array}$ & \begin{tabular}{|c} 
Extract \\
type
\end{tabular} & \begin{tabular}{|c} 
Extract yields \\
$($ w/w \%) \\
\end{tabular} & $\begin{array}{l}\text { Total phenolic } \\
\text { content }^{a} \pm \text { S.D. } \\
\end{array}$ & $\begin{array}{l}\text { Total flavonoid } \\
\text { content } \pm \text { S.D. } \\
\end{array}$ \\
\hline \multirow{2}{*}{ Flower } & EtOH & 2.79 & $368.11 \pm 2.02 * *$ & $214.03 \pm 0.98^{*}$ \\
\hline & $\mathrm{dH}_{2} \mathrm{O}$ & 0.42 & $310.65 \pm 2.36^{*}$ & $192.44 \pm 0.66^{* *}$ \\
\hline \multirow{2}{*}{ Stem } & EtOH & 2.32 & $234.70 \pm 2.09^{*}$ & $153.50 \pm 1.34^{*}$ \\
\hline & $\mathrm{dH}_{2} \mathrm{O}$ & 8.59 & $206.62 \pm 1.28 *$ & $139.18 \pm 1.42 * *$ \\
\hline
\end{tabular}

${ }^{a} \mathrm{mg}$ equivalent of gallic acid (GAE) per $\mathrm{g}$ of extract.

b S.D.: Standard deviation $(\mathrm{n}=3)$.

${ }^{\mathrm{c}} \mathrm{mg}$ equivalent of quercetin (QE) per $\mathrm{g}$ of extract.

$* p$ value of $<0.05 ; * * p$ value of $<0.01$.

As given in Table 1, EtOH extracts prepared from the flower of CSS were found the highest amount of total phenol $(368.11 \pm 2.02 \mathrm{mg} / \mathrm{g}$ extract as GAE, $p<0.01)$, and flanvanoid $(214.03 \pm 0.98 \mathrm{mg} / \mathrm{g}$ extract as QE, $p<0.05$ ), while $\mathrm{dH}_{2} \mathrm{O}$ extracts prepared from stem of CSS were identified to possess the lowest total phenolic and flavonoid quantities $(206.62 \pm 1.28 \mathrm{mg} / \mathrm{g}$ extract as GAE, $p<0.05$ and 139.18 $\pm 1.42 \mathrm{mg} / \mathrm{g}$ extract as QE, $p<0.01$, respectively).

\subsection{Antioxidant activity results}

Antioxidant activity of CSS extracts were evaluated using free radical scavenging against DPPH and ABTS radicals, and the results were presented inhibition $(\%) \pm \mathrm{SD}$ in Figure 2. Among the tested extracts, the highest DPPH radical scavenging activity was observed in the EtOH extract of flower $(92.14 \pm 2.03 \%, p<0.05)$, which was following by $\mathrm{dH}_{2} \mathrm{O}$ extract of flower $(80.01 \pm 0.68 \%, p<0.05)$. In the ABTS assay, the extracts prepared with $\mathrm{dH}_{2} \mathrm{O}$ exhibited higher inhibition activity, comparing the EtOH extracts, in which flower part showed the weakest inhibition potential $(53.78 \pm 0.61 \%, p<0.05)$ (Figure 2).

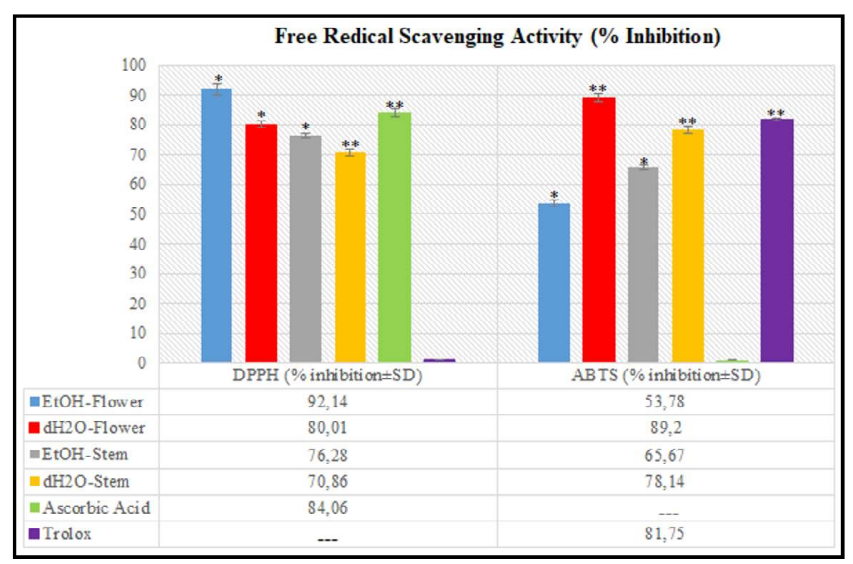

Figure 2: Free radical scavenging activities of CSS extracts at $1000 \mu \mathrm{g} / \mathrm{ml}$.

(The values were expressed as inhibition $(\%) \pm$ standard deviation. Ascorbic acid; reference for DPPH assay. Trolox; a commercial standard for ABTS assay. ${ }^{*} p$ value of $<0.05 ; * * p$ value of $<0.01$.).

As for FRAP and CUPRAC ion reducing power capacities of different parts of CSS, the results were summarized in Table 2 regarding of their absorbance values $( \pm \mathrm{SD})$. In general, the tested extracts exerted powerful FRAP ion-reducing capacity, whilst they showed moderate reducing power activity on CUPRAC. As similar with DPPH assay results, $\mathrm{dH}_{2} \mathrm{O}$ extracts possessed lower FRAP value than EtOH extracts. On the other hand, EtOH extract obtained from flower part of CSS were found to have the highest FRAP value $(3.138 \pm 0.08, p<0.01)$, closely followed by flower- $\mathrm{dH}_{2} \mathrm{O}$ extract $(2.906 \pm 0.62, p<0.05)$. On the contrary FRAP findings, stem extracts prepared with EtOH and $\mathrm{dH}_{2} \mathrm{O}$ demonstrated higher CUPRAC value (2.207 $\pm 0.92 p<0.01$ and $2.061 \pm 0.43, p<0.05$, respectively) than those of the flower extracts of the plant (Table 2).

Table 2: Reducing power capacities of CSS extracts at $1000 \mu \mathrm{g} / \mathrm{ml}$

\begin{tabular}{|c|c|c|c|}
\hline \multirow{2}{*}{$\begin{array}{l}\text { Plant } \\
\text { parts }\end{array}$} & \multirow{2}{*}{$\begin{array}{c}\text { Extract } \\
\text { type }\end{array}$} & \multicolumn{2}{|c|}{ Reducing power capacity (Absorbance ${ }^{\mathrm{a}} \pm$ S.D.) } \\
\hline & & FRAP & CUPRAC \\
\hline \multirow{2}{*}{ Flower } & $\mathrm{EtOH}$ & $3.138 \pm 0.08 * *$ & $1.214 \pm 0.26^{* *}$ \\
\hline & $\mathrm{dH}_{2} \mathrm{O}$ & $2.906 \pm 0.62 *$ & $1.328 \pm 0.55^{*}$ \\
\hline \multirow{2}{*}{ Stem } & $\mathrm{EtOH}$ & $2.314 \pm 0.05^{*}$ & $2.207 \pm 0.92 * *$ \\
\hline & $\mathrm{dH}_{2} \mathrm{O}$ & $2.115 \pm 0.19^{*}$ & $2.061 \pm 0.43^{*}$ \\
\hline \multicolumn{2}{|c|}{$\operatorname{Trolox}^{\mathrm{b}}(1000 \mu \mathrm{g} / \mathrm{ml})$} & $3.408 \pm 0.36$ & $2.577 \pm 0.18$ \\
\hline
\end{tabular}

${ }^{a}$ Higher absorbance indicates greater antioxidant activity.

${ }^{\mathrm{b}}$ Trolox; reference for FRAP and CUPRAC assays.

${ }^{*} p$ value of $<0.05 ; * * p$ value of $<0.01$. 


\subsection{Neuroprotective activities}

The EtOH and $\mathrm{dH}_{2} \mathrm{O}$ extracts obtained from stem and flower of the plant were evaluated for their inhibitory activities against AChE, BChE and TYR at 100, 200, 400, 800 and $1000 \mu \mathrm{g} / \mathrm{ml}$ concentrations, using galanthamine and $\alpha$-Kojic acid as the reference drugs. Neuroprotective potentials of the tested extracts were summarized in Table 3. According to the results, extracts prepared from flowers of the plant exhibited noticeable enzyme inhibitions against the mentioned enzymes at the tested concentrations (Table 3).

Table 3: Neuroprotective potentials of CSS extracts at $1000 \mu \mathrm{g} / \mathrm{ml}$

\begin{tabular}{|c|c|c|c|c|}
\hline \multirow{2}{*}{$\begin{array}{l}\text { Plant } \\
\text { parts }\end{array}$} & \multirow{2}{*}{$\begin{array}{c}\text { Extract } \\
\text { type }\end{array}$} & \multicolumn{3}{|c|}{$\%$ Inhibition \pm SD $^{a}$} \\
\hline & & AChE & BChE & TYR \\
\hline \multirow{2}{*}{ Flower } & EtOH & $60.18 \pm 1.37 *$ & $72.15 \pm 0.98^{* *}$ & $55.04 \pm 2.04 * *$ \\
\hline & $\mathrm{dH}_{2} \mathrm{O}$ & $41.55 \pm 1.90^{* *}$ & $68.21 \pm 0.42 *$ & $34.86 \pm 0.75 * *$ \\
\hline \multirow{2}{*}{ Stem } & $\mathrm{EtOH}$ & $38.50 \pm 1.43^{* *}$ & $45.72 \pm 1.19 * *$ & $26.34 \pm 0.68 * *$ \\
\hline & $\mathrm{dH}_{2} \mathrm{O}$ & $22.16 \pm 1.05^{*}$ & $--^{d}$ & $--^{d}$ \\
\hline \multicolumn{2}{|c|}{ Galantamine $^{b}$} & $89.18 \pm 0.06$ & $86.44 \pm 0.80$ & --- \\
\hline \multicolumn{2}{|c|}{$\alpha$-Kojic acid $^{c}$} & --- & --- & $83.17 \pm 0.35$ \\
\hline
\end{tabular}

${ }^{a}$ The values were given as inhibition $(\%) \pm$ standard deviation $(n=3)$.

${ }^{\mathrm{b}}$ Galantamine; a commercial standard for AChE and BChE enzymes

${ }^{c} \alpha$-Kojic acid; a commercial standard for TYR enzyme.

${ }^{\mathrm{d}}$ No inhibitory activity.

$* p$ value of $<0.05 ; * * p$ value of $<0.01$.

As can be seen in Table 3, both EtOH and $\mathrm{dH}_{2} \mathrm{O}$ extracts of CSS were found to have the highest inhibition against $\mathrm{AChE}$, while they demonstrated the lowest one towards TYR enzyme. Among the tested extracts, the higher neuroprotective activity was observed with the extracts obtained from flower part of CSS at any concentrations, as compatible with the results of total polyphenolic contents. Enzyme inhibitory potentials of the extracts resulted in the superiority of flower-EtOH extract against $\mathrm{AChE}, \mathrm{BChE}$ and TYR with $60.18 \pm 1.37(p<0.05), 72.15 \pm 0.98(p<0.01)$ and $55.04 \pm 2.04(p<0.01)$ inhibition percentage at $1000 \mu \mathrm{g} / \mathrm{mL}$, respectively. In other words, the $\mathrm{dH}_{2} \mathrm{O}$ extract obtained from the stem of the plant was found the lowest inhibition potential on $\operatorname{AChE}(22.16 \pm 1.05 \%$ inhibition, $p<0.05)$, and it was inactive against BChE and TYR enzymes (Table 3).

\section{Discussion}

Free radicals and reactive oxygen species generated by oxidation reaction in human body cause oxidative-stress related disorders, neurodegeneration and certain chronic diseases like cancer, diabetes and cardiovascular disease (Xie et al., 2016; Gezici et al., 2017). Antioxidants are substances and compounds that are able to neutralize oxidative damage caused by free radicals and oxygen species. Herewith, antioxidants have vital importance in the maintenance of human health and prevention of oxidative-stress related disease. Due to the possible benefits of antioxidants, food and pharmaceutical industries are particularly enriched their products with synthetic antioxidants, which may cause to toxic-side effects for human health. Thus, there is a growing trend to substitute synthetic antioxidants with natural antioxidants obtained from medicinal and aromatic plants (Iqbal, 2013; Biradar, 2015; Newman and Crag, 2016; Gezici and Sekeroglu, 2019b).
Alzheimer's disease (AD) and Parkinson disease (PD), characterized by memory dysfunction and loss of behavior skills, are the most common neurodegenerative diseases, and their incidence increases rapidly around the world. Reduction of acetylcholine and butrylcholine levels in the brain are the most remarkable biochemical mechanism for treatment of AD (Ahmed et al., 2013; Harris, 2019). That's why, $\mathrm{AD}$ are treated by use of agents that can restore the level of acetylcholine and butrylcholine via, inhibition of cholinesterase enzymes including acetylcholinesterase (AChE) and butrylcholinesterase (BChE), whilst inhibition tyrosinase (TYR) enzyme is closely found to relating with pathogenesis of PD (Tundis et al., 2016; Rehman et al., 2019). Synthetic inhibitors such as tacrine, rivastigmine, $\alpha$-kojic acid and galanthamine used as cholinesterase and tyrosinase inhibitors for treatment of $\mathrm{AD}$ and $\mathrm{PD}$ have been reported to have several side effects for human health. Thus, AChE, BChE and TYR inhibitors obtained from herbal sources have been gaining more interest for the last decades, and a number of researchers have focused on searching novel and safe inhibitors for the management of neurodegenerative diseases (Perry and Howes, 2011; Tundis et al., 2016; Senol et al., 2018; Sekeroglu and Gezici, 2019; Wang et al., 2020).

Take into consideration our ongoing research to discover plant-based enzyme inhibitors, CSS extracts were screened for their enzyme inhibitory potentials towards AChE, BChE and TYR enzymes combining with free radical scavenging activities as well as ionreducing capacities in the presented research. Even though, chemical profiles and biochemical contents of extracts and essential oils of CSS were revealed by a few previous researches (Gulluce et al., 2004; Shehab and Abu-Gharvieh, 2012; Abu-Gharbieh and Ahmed, 2016; Dunkić et al., 2017; Ali-Shtayeh et al., 2018). The flower and stem extracts from CSS were assessed regarding of neuroprotective potentials and antioxidant activities by using different assays for the first time in the current study. Previous reports on phytochemical compositions of CSS showed that it possess rich bioactive secondary metabolites, which could be presumably responsible for notable anti-cholinesterase activities of the CSS extracts.

In regards of antioxidant analyses of the extracts, they exerted remarkable free radial scavenging and ion-reducing capacities, which were consistent with former studies performed to determine antioxidant potentials of CSS extracts and essential oils. These potential antioxidant capacities of CSS plant extracts can be explained by the plant's major phenolic constituents including quercetin, rosmarinic acid and gallic acid that are considered as effective antioxidant compounds, as reported previously (Gullluce et al., 2004; Abu-Gharbieh and Ahmed, 2016; Ali-Shtayeh et al., 2018). On the other hand, rich phenolic contents of the extracts may probably contribute strong neuroprotective and antioxidant activities to the plant. Accordingly, CSS plant extracts have a valuable source for management of oxidative stress-related diseases and neurodegenerative disorders as a food supplement.

\section{Conclusion}

In this study, the flower and stem extracts of CSS revealed high antioxidant and anti-cholinesterase activities. To the best of our knowledge, we disclose the first study on enzyme inhibitory effects of the plant extracts as well as the antioxidant activities tested herein. Based on these results aerial part of the plant could be considered as a natural agent for prevention oxidative damage and 
inhibition the key enzymes linked to pathogenesis of $\mathrm{AD}$. In addition, the results obtained from current research may provide a valuable data for preparing a good model in order to develop new herbal drug formulations in nutraceutical and pharmacological industries. However, further research is needed to conduct in terms of uncover bioactive compounds with molecular mechanisms.

\section{Acknowledgments}

This study was financially supported by the Scientific Research Project Unit of Kilis 7 Aralik University, Kilis-Turkey (BAP Project No: 12292MAP). The authors thank to the Medicinal and Aromatic Plants Laboratory at Advanced Technology Application and Research Center (ATARC) Kilis 7 Aralik University for providing technical support.

\section{Conflict of interest}

The authors declare that there are no conflicts of interest in the course of conducting the research. All the authors had final decision regarding the manuscript and decision to submit the findings for publication.

\section{References}

Abu-Gharbieh, E.; Shehab, N.G.; and Khan, S.A. (2013). Anti-inflammatory and gastroprotective activities of the aqueous extract of Micromeria fruticosa (L.) Druce ssp Serpyllifolia in mice. Pak. J. Pharm. Sci., 26:799-803.

Abu-Gharbieh, E. and Ahmed, N.G. (2016). Bioactive content, hepatoprotective and antioxidant activities of whole plant extract of Micromeria fruticosa (L.) Druce ssp Serpyllifolia F Lamiaceae against Carbon tetrachloride-induced hepatotoxicity in mice. Trop. J. Pharm. Res., 15(10):2099-2106.

Ahmed, F.; Ghalib, R.M.; Sasikala, P. and Ahmed, K.M. (2013). Cholinesterase inhibitors from botanicals. Pharmacog. Rev., 7(14):121.

Alam, A. (2019). Herbs that heal Spices: The hoard of natural remedies. Ann. Phytomed., 8(2):7-18.

Ali-Shtayeh, M.S.; Jamous, R.M.; Abu-Zaitoun, S.Y.; Akkawi, R.J.; Kalbouneh, S.R.; Bernstein, N. and Dudai, N. (2018). Chemical profile and bioactive properties of the essential oil isolated from Clinopodium serpyllifolium (M. Bieb.) Kuntze growing in Palestine. Ind. Crop. Prod., 124: 617-625.

Batiha, G.E.S.; Beshbishy, A.M.; Mulla, Z.S.; Ikram, M.; El-Hack, M.E.A.; Taha, A.E.; Algammal A.M. and Elewa, Y.H.A. (2020). The Pharmacological Activity, Biochemical Properties, and Pharmacokinetics of the Major Natural Polyphenolic Flavonoid: Quercetin. Foods, 9(3): 374. https://doi.org/10.3390/foods9030374.

Baytop, T. (1999). Therapy with Medicinal Plants in Turkey (Past and Present), Second ed. Nobel Týp Kitabevi, Istanbul, Turkey.

Biradar, D.P. (2015). Medicinal plants and phytomedicines. Ann. Phytomed., 4(1): $1-5$.

Blois, M.S. (1958). Antioxidant determinations by the use of a stable free radical. Nature, 181(4617):1199-1200.

Dunkiæ, V.; Kremer, D.; Grubešiæ, R.J.; Rodríguez, J.V.; Ballian, D.; Boguniæ, F.; and Stabentheiner, E. (2017). Micromorphological and phytochemical traits of four Clinopodium L. species (Lamiaceae). S. Afr. J. Bot., 111:232-241.

Ellman, G.L.; Courtney, K.D.; Andres Jr, V. and Featherstone, R.M. (1961). A new and rapid colorimetric determination of acetylcholinesterase activity. Biochem. Pharmacol., 7:88-95. https://doi.org/10.1016/ 0006-2952(61)90145-9.
FAO. (2018). Food and Agriculture Organization of the United Nations. Ankara, 2018. Biodiversity of Turkey. Contribution of Genetic Resources to Sustainable Agricultural and Food Systems. http:// www.fao.org/3/CA1517EN/ca1517en.pdf

Gezici, S. and Sekeroglu, N. (2019a). Current perspectives in the application of medicinal plants against cancer: Novel therapeutic agents. Anticancer Agents Med. Chem., 19(1):101-111. https://doi.org/ $10.2174 / 1871520619666181224121004$.

Gezici, S. and Sekeroglu, N. (2019b). Neuroprotective potential and phytochemical composition of acorn fruits. Ind. Crop. Prod. 128: 13-17. https://doi.org/10.1016/j.indcrop.2018.10.082.

Gezici, S.; Sekeroglu, N. and Kijjoa, A. (2017). In vitro Anticancer activity and antioxidant properties of essential oils from Populus alba L. and Rosmarinus officinalis L. from South Eastern anatolia of Turkey. Ind. J. Pharm. Educ. Res., 51(3):498-503. https://doi.org/ 10.5530/ijper.51.3s.74.

Gulluce, M.; Sökmen, M.; 'ahin, F.; Sökmen, A.; Adigüzel, A. and Özer, H. (2004). Biological activities of the essential oil and methanolic extract of Micromeria fruticosa (L.) Druce ssp serpyllifolia (Bieb) PH Davis plants from the eastern Anatolia region of Turkey. J. Sci. Food Agric., 84(7):735-741.

Guner, A.; Aslan, S.; Ekim, T.; Vural, M. and Babaç, M.T. (edlr.). (2012). Turkey plant list (Vascular plants). Association of Mezahat Gokyigit Botanical Garden and Flora Research Publication, Istanbul. https:/ /www.bizimbitkiler.org.tr/v2/index.php.

Harris, R.E. (2019). Epidemiology of chronic disease: Global perspectives. Jones and Bartlett Publishers.

Iqbal, M. (2013). From medicine to phytomedicine. Ann. Phytomed., 2:1-2.

Newman, D.J. and Cragg, G.M. (2016). Natural products as sources of new drugs from 1981 to 2014. J. Nat. Prod., 79(3):629-661. https:// doi.org/10.1021/acs.jnatprod.5b01055.

Nguyen, V.T.; Van Vuong, Q.; Bowyer, M.C.; Van Altena, I.A. and Scarlett, C.J. (2015). Effects of different drying methods on bioactive compound yield and antioxidant capacity of Phyllanthus amarus. Dry. Technol., 33(8):1006-1017.

Oyaizu M. (1986). Studies on product of browning reaction prepared from glucose amine. Jpn. J. Nutr., 44:307-315.

Perry, E. and Howes, M.J.R. (2011). Medicinal plants and dementia therapy: Herbal hopes for brain aging? CNS Neurosci. Ther., 17(6):683-698.

Re, R.: Pellegrini, N.: Proteggente, A.: Pannala, A.: Yang, M. and Rice-Evans, C. (1999). Antioxidant activity applying an improved ABTS radical cation decolorization assay. Free Radical. Biol. Med., 26(9-10): $1231-1237$.

Rehman, M.U.; Wali, A.F.; Ahmad, A.; Shakeel, S.; Rasool, S.; Ali, R. and Khan, R. (2019). Neuroprotective strategies for neurological disorders by natural products: An update. Curr. Neuropharmacol., 17(3):247-267.

Sekeroglu, N. and Gezici, S. (2019). Astragalus neurocarpus Bioss. as a potential source of natural enzyme inhibitor associated with Alzheimer's and Parkinson diseases along with its rich polyphenolic content and antioxidant activities. Ann. Phytomed., 8(1):82-87.

Sekeroglu, N.; Senol, F.S.; Orhan, I.E.; Gulpinar, A.R.; Kartal, M. and Sener, B. (2012). In vitro prospective effects of various traditional herbal coffees consumed in Anatolia linked to neurodegeneration. Food Res. Int., 45: 197-203. https://doi.org/10.1016/j.foodres.2011.10.0088.

Senol, F.S.; Sekeroglu, N.; Gezici, S.; Kilic, E. and Orhan, Ý.E. (2018). Neuroprotective potential of the fruit (acorn) from Quercus coccifera L. Turk. J Agric. For., 42:82-87. https://doi.org/10.3906/ tar-1711-18. 
Shehab, N.G. and Abu-Gharbieh, E. (2012). Constituents and biological activity of the essential oil and the aqueous extract of Micromeria fruticosa (L.) Druce subsp. serpyllifolia. Pak. J. Pharm. Sci., 25(3).

Singleton, V.L. and Rossi, J.A. (1965). Colorimetry of total phenolics with phosphomolybdic-phosphotungstic acid reagents. Am. J. Enol. Vitic., 16:144-158.

Tošiæ, S.; Stojièiæ, D.; Stankov-Jovanovic, V.; Mitic, V.; Mihajilov-Krstev, T. and Zlatkovic, B. (2015). Chemical composition, antioxidant and antimicrobial activities of micropropagated and native Micromeria pulegium (Lamiaceae) extracts. Oxid. Commun., 38(1):55-66.

The Plant List. (2020). Version 1.1. Published on the Internet; http:// www.theplantlist.org/

http://www.theplantlist.org/1.1/browse/A/Lamiaceae/ Clinopodium/ Accessed date: 11 May, 2020.

TUBIVES. (2020). Turkish Plants Data Service (TUBIVES) Version 2.0 BETA. Accessed date 11 May, 2020. http:/www.tubives.com/

Tundis, R.; Bonesi, M.; Menichini, F. and R Loizzo, M. (2016). Recent knowledge on medicinal plants as source of cholinesterase inhibitors for the treatment of dementia. Mini-Rev. Med. Chem., 16(8):605-618.
Van Wyk, B.E. and Wink, M. (2018). Medicinal plants of the world. CABI. Second Ed, Briza Publication.

Wang, T.Y.; Li, Q. and Bi, K.S. (2018). Bioactive flavonoids in medicinal plants: Structure, activity and biological fate. Asian J. Pharm. Sci., 13(1): 12-23.

Wang, Z.; He, C. and Shi, J.S. (2020). Natural products for the treatment of neurodegenerative diseases. Curr. Med. Chem. https://doi.org/ $10.2174 / 0929867326666190527120614$.

Woisky, R.G. and Salatino, A. (1998). Analysis of propolis: Some parameters and procedures for chemical quality control. J. Apic. Res., 37:99-105. https://doi.org/10.1080/00218839.1998.11100961.

Xie, J.H.; Jin, M.L.; Morris, G.A.; Zha, X.Q.; Chen, H.Q.; Yi, Y. and Shang, P. (2016). Advances on bioactive polysaccharides from medicinal plants. Crit. Rev. Food Sci. Nutr., 56(sup1):60-84.

Xu, D.P.; Li, Y.; Meng, X.; Zhou, T.; Zhou, Y.; Zheng, J.; ... and Li, H.B. (2017). Natural antioxidants in foods and medicinal plants: Extraction, assessment and resources. Int. J. Mol. Sci., 18(1):96. https://doi.org/ $10.3390 / \mathrm{ijms} 18010096$.

Citation: Sevgi Gezici, Didem Koçum, Fatih Yayla, Nazim Sekeroglu and Adnan A. Khan (2020). Screening for in vitro antioxidant activities, polyphenolic contents and neuroprotective potentials of Clinopodium serpyllifolium subsp. serpyllifolium endemic to Turkey. Ann. Phytomed., 9(1):181-186. http://dx.doi.org/10.21276/ap.2020.9.1.23 